\title{
On the Tension between Sex Equality and Religious Freedom
}

\section{Citation}

Cass R. Sunstein, On the Tension between Sex Equality and Religious Freedom (Public Law \& Legal Theory Working Papers No. 167, 2007).

\section{Published Version}

http://chicagounbound.uchicago.edu/public_law_and_legal_theory/214/

\section{Permanent link}

http://nrs.harvard.edu/urn-3:HUL.InstRepos:12911340

\section{Terms of Use}

This article was downloaded from Harvard University's DASH repository, and is made available under the terms and conditions applicable to Other Posted Material, as set forth at http:// nrs.harvard.edu/urn-3:HUL.InstRepos:dash.current.terms-of-use\#LAA

\section{Share Your Story}

The Harvard community has made this article openly available.

Please share how this access benefits you. Submit a story.

Accessibility 


\section{University of Chicago Law School Chicago Unbound}

\section{On the Tension between Sex Equality and Religious Freedom}

Cass R. Sunstein

Follow this and additional works at: http://chicagounbound.uchicago.edu/ public_law_and_legal_theory

Part of the Law Commons

\section{Recommended Citation}

Cass R. Sunstein, "On the Tension between Sex Equality and Religious Freedom" (Public Law \& Legal Theory Working Papers No. $167,2007)$.

This Working Paper is brought to you for free and open access by the Working Papers at Chicago Unbound. It has been accepted for inclusion in Public Law and Legal Theory Working Papers by an authorized administrator of Chicago Unbound. For more information, please contact unbound@law.uchicago.edu. 


\title{
CHICAGO
}

Public LAW AND LegAL THEORY WORKING PAPER NO. 167

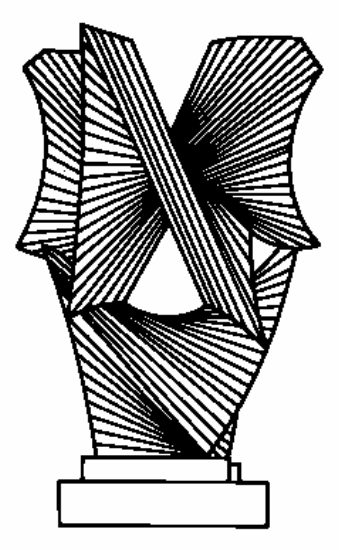

\section{ON THE TENSION BETWEEN SEX EQUALITY AND RELIGIOUS FREEDOM}

\author{
Cass R. Sunstein \\ THE LAW SCHOOL \\ THE UNIVERSITY OF CHICAGO
}

June 2007

This paper can be downloaded without charge at the Public Law and Legal Theory Working

Paper Series: http://www.law.uchicago.edu/academics/publiclaw/index.html and The Social Science Research Network Electronic Paper Collection:

http://ssrn.com/abstract_id=995325 
Preliminary draft 3/27/07

all rights reserved

\title{
On the Tension between Sex Equality and Religious Freedom
}

\section{Cass R. Sunstein*}

\begin{abstract}
When, if ever, is it legitimate for law to ban sex discrimination by religious institutions? It is best to approach this question by noticing that most of the time, ordinary civil and criminal law are legitimately applied to such institutions. For example, members of religious organizations cannot commit torts, even if the commission of torts is said to be part of their religious practices. Many people seem to accept what might be called an Asymmetry Thesis, which holds that sex equality principles may not be applied to religious institutions, whereas ordinary civil and criminal law may indeed be applied to them. This essay argues that the Asymmetry Thesis cannot be defended, and that much of the time, sex equality principles are properly applied to religious institutions. Discussion is also devoted to the controversial idea that facially neutral laws may be applied to religious institutions even if they have a severe adverse effect on religious practices.
\end{abstract}

My topic here is an insufficiently explored puzzle. In the United States and in many other nations, it is generally agreed that most ordinary law, both civil and criminal, is legitimately applied to religious organizations. Thus, for example, a secular government may prohibit members of a religious institution from engaging in murder, kidnapping, assault, cruelty to animals, or intentional infliction of emotional distress, even if those acts are part of religious ceremony or otherwise guided or even mandated by religious precepts.

At the same time, it is generally agreed that there are important limits on the extent to which the law of sex discrimination is legitimately applied to religious organizations. Often those limits are respected voluntarily by governments. States do not, for example, require the Catholic Church to ordain women as priests, and under existing law, religious institutions are plainly permitted to engage in acts that would be

\footnotetext{
* Karl N. Llewellyn Distinguished Service Professor, Law School and Department of Political Science, University of Chicago. This essay is forthcoming in a book edited by Robert Reich and Debra Satz on the work of Susan Moller Okin, and I am grateful to Reich and Satz for their valuable comments. Special thanks to Okin herself, in memoriam; her important work on multiculturalism and its limits inspired the discussion here.
} 
unacceptable discrimination if carried out by a secular entity. ${ }^{1}$ Interference with religious autonomy is pervasive under the ordinary criminal and civil law. But such interference is usually absent if sex discrimination is the problem that the government is seeking to address. Indeed, such interference is sometimes thought to be unconstitutional or to be inconsistent with the most fundamental ideals - to violate the defining commitment to respect for religious institutions.

An important commonplace of democratic theory and practice might therefore be deemed the Asymmetry Thesis. According to the Asymmetry Thesis, it is unproblematic to apply ordinary civil and criminal law to religious institutions, but problematic to apply the law forbidding sex discrimination to those institutions. Thus it is uncontroversially acceptable to prevent priests from beating up women (or anyone else) as part of a religious ceremony, or to ban Orthodox Jews from assaulting Reform women rabbis (even if they are sincerely motivated by a religiously-founded idea of a male rabbinate); but it is often thought unacceptable to ban sex segregation in religious education, ${ }^{2}$ or to prohibit religious groups from excluding women from certain domains.

What is the source of this asymmetry? Can it be defended? I believe that in the end, there is no good defense of the Asymmetry Thesis, and that in many contexts, neither liberal ideals nor the Constitution should be taken to forbid government from banning sex discrimination by religious institutions. To sustain this argument, it will be necessary to say something about the nature of liberal ideals.

\section{Puzzles and Conflicts}

To anchor the discussion, consider some potential conflicts between sex equality and freedom of religion, conflicts that arise in one or another form in many nations:

1. Certain Jewish synagogues educate boys separately from girls, and certain Jewish schools refuse to admit girls. Some Jewish girls and their parents contend that this

\footnotetext{
1 American law makes the basic prohibitions on employment discrimination inapplicable where religion, sex, or national origin is "a bona fide occupational qualification reasonably necessary to the normal operation of that particular business or enterprise." 42 U.S.C. 2000e-2(e). The prohibition is generally inapplicable "to a religious corporation, association, educational institution, or society with respect to the employment of individuals of a particular religion to perform work connected with the carrying on by such corporation, association, educational institution, or society of its activities.” 42 USC 2000e-1.

${ }^{2}$ Of course the American Constitution applies only to the state, and not to private institutions; hence the Asymmetry Thesis has its force when government goes beyond the Constitution to apply a prohibition on sex discrimination to most private institutions but not to religion.
} 
is a form of sex discrimination that contributes to sex-role stereotyping, in a way that produces damaging effects on boys and especially girls, and that may even compromise fair equality of opportunity.

2. A Catholic university refuses to tenure several women teachers in its canon law department. A disappointed faculty member complains that this is a form of employment discrimination. ${ }^{3}$ The university responds that courts should not be allowed intervene in a religious matter of this kind.

3. A young man trains and studies for ordination to the priesthood of the Society of Jesus. He is repeatedly subjected to sexual harassment by two ordained priests. The harassment takes the form of unwanted sexual comments, propositions, and pornographic mailings. He brings suit for employment discrimination. ${ }^{4}$ It is objected that the suit compromises religious liberty.

4. Mormon employers engage in various practices of sex discrimination in employment. They refuse to hire women for certain jobs; they claim that being male is an occupational qualification, imposed in good faith, for certain positions. These practices are undertaken in the private sector, in institutions that both have and do not have explicitly religious functions.

5. A Western nation allows immigrant men to bring in multiple wives. It recognizes their polygamous marriages and various discriminatory practices (including "assigning" teenage girls to older men for marriage) that accompany certain religious convictions.

Freedom of religion has a central place in the liberal tradition, and in the United States, as elsewhere, the law forbidding sex discrimination contains important exemptions for religious institutions. Federal law itself permits "bona fide occupational qualifications" based on sex, and usually the exemptions are voluntary. But courts have said that the free exercise clause of the Constitution requires courts to refrain from adjudicating sex discrimination suits by ministers against the church or religious institution employing them—even though ministers could certainly complain of assault

\footnotetext{
${ }^{3}$ See EEOC v. Catholic University of America, 856 F. Supp. 1 (DDC 1994), affirmed, 83 F.2d 455 (DC Cir. 1994).

${ }^{4}$ Bollard v. California Province of the Society of Jesus, 1998 U.S. Dist. LEXIS 7563 (May 15, 1998).
} 
or rape. ${ }^{5}$ In the religious context, this principle of religious immunity from secular law has been read quite broadly, to apply to lay employees of institutions (including high schools and universities) whose primary duties consist of spreading the faith or supervising religious rituals. ${ }^{6}$

As I have suggested, the resulting doctrine is a puzzle in light of the fact that almost no one believes that in general, religious organizations can be exempted from most of the law forbidding civil and criminal wrongs. The puzzle is not only obvious but also important, for there is good reason to believe that some of the most pernicious forms of sex discrimination are a result of the practices of religious institutions, which can produce internalized norms of subordination. ${ }^{7}$ Those internalized norms might undermine equality of opportunity itself, as when women scale back their aspirations to conform to those internalized norms. People's preferences, especially in the domain of sex equality, should not be taken as given, or as coming from the sky; discriminatory beliefs and rolebased choices are often produced by a discriminatory society. Religious practices often contribute a great deal to such beliefs and choices, on the part of men and women alike. In such circumstances it is not even clear whether the relevant preferences are authentically "theirs." The remedy of "exit" — the right of women to leave a religious group or order-is crucial, but in practice it may not be available. Indeed, “exit” will not be sufficient when girls have been taught in such a way as to be unable or unwilling to scrutinize the practices with which they have grown up. Here in particular, the ideal of equal opportunity is compromised.

There is a further problem. Seemingly isolated decisions of individual women may help establish and reproduce norms of inequality that are injurious to other women. Women interested in sex equality therefore face a collective action problem; rational acts by individual women can help sustain discriminatory norms. To say the least, it is not obvious how a liberal society should respond to this problem. But some measures prohibiting sex discrimination may make things better.

\footnotetext{
${ }^{5}$ See, e.g., Young v. Northern Illinois Conference of United Methodist Church, 21 F.3d 184 (7th Cir. 1994)

6 EEOC v. Catholic University of America, 83 F.3d 455 (DC Cir. 1994).

7 To say this is not to deny that norms of sex equality are often an outgrowth of religious beliefs as well, nor is it to offer a general view about whether the world's religions promote or deny sex equality; it is doubtful that any general view would make much sense.
} 


\section{The Smith Principle: Generality and Administrability}

To answer the underlying question, and to understand the asymmetry principle, it is necessary to step back a bit and say a offer some more general words about the relationship between constitutional law and religious institutions. In the United States, there is a sharp and continuing debate about whether a state may apply "facially neutral" laws to religious institutions. ${ }^{8} \mathrm{~A}$ law is facially neutral if it does not specifically aim at religious practices or belief; thus a law banning the payment of taxes, the burning of animals, or the use of peyote is facially neutral, whereas a law banning the Lord's Prayer, or the practice of Buddhism, is facially discriminatory.

Under current law in the United States, any facially neutral law is presumed to be constitutionally acceptable. ${ }^{9}$ The validity of all facially neutral laws may be deemed "the Smith principle," after the highly controversial Supreme Court decision that established it. Congress attempted to "overrule" Smith with the Religious Freedom Restoration Act, which would have required the state to provide a strong secular justification for any law that burdened religion, even if the law was neutral on its face; but the Court struck down the Religious Freedom Restoration Act as beyond legislative power. ${ }^{10}$

The Smith principle seems to be undergirded by two distinct ideas. The first involves an understanding of the relationship between liberty and the political safeguards that are expected to accompany democratic processes: A secular law that is neutral on its face is highly unlikely to interfere with religious liberty, properly conceived. The reason is that the democratic process is a sufficient safeguard against laws that are facially neutral but oppressive. The very neutrality (and hence generality) of such laws guarantees against oppressiveness, for when a number of groups are subject to law, they are likely to mobilize against them and to prevent their enactment (unless there are very

\footnotetext{
${ }^{8}$ Michael McConnell, Free Exercise Revisionism and the Smith Decision, 57 U Chi L Rev 1109 (1990); Abner Greene, The Political Balance of the Religion Clauses, 102 Yale LJ 1611 (1993).

${ }^{9}$ Employment Division, Department of Human Services v. Smith, 494 U.S. 872 (1990). Technically, Smith holds that a facially neutral law will be upheld so long as it has a "rational basis," unless it is discriminatorily motivated. The Court did not overrule Sherbert v. Verner, 374 U.S. 398 (1963) (holding that a state may not deny unemployment benefits to a Seventh-Day Adventist who was fired because she would not work on Saturday) or Wisconsin v. Yoder, 406 U.S. 205 (1972) (allowing Amish teenagers to be exempted from a requirement of school attendance until the age of 16); but it did read those cases extremely narrowly. It should be noted that the Smith decision was surprising as well as controversial and that it remains an object of continuing debate, not only in political and academic circles but also within the Supreme Court itself.

10 City of Boerne v. Flores, 117 S Ct 2157 (1997).
} 
good reasons for them). But if a law is narrowly tailored so as to discriminate against a particular group - no public religious services for Catholics or Buddhists, for examplethe ordinary political safeguards are not in play. By emphasizing the value of such safeguards, and their relevance to constitutional law, Smith is connected with longstanding liberal themes, suggesting that a requirement of generality provides a political check on unjustified interferences with freedom.

The second basis for the Smith principle is one of judicial administrability: Even if some facially neutral laws raise serious questions in principle, it is very hard to administer a test for constitutionality (or political legitimacy) that would require a kind of balancing of the opposing interests. Suppose, for example, that courts ruled that burdens on religious liberty are justified if and only if the secular reason for the burdens outweighs the intrusion on religion. We can imagine some easy cases here. A neutral tax law, for example, would almost certainly be upheld against the objection that it intrudes on the religious convictions of some, because a tax system would be very hard to run if religious objectors could exempt themselves. But many cases would be exceedingly hard for courts to handle, simply because of the difficulty of balancing the claims on both sides. The best defense of the Smith principle is that even if it protects religious liberty too little, it comes close to protecting religious liberty enough —and it does so with the only principle that real-world institutions can apply fairly and easily.

Under the Smith principle, facially neutral laws are legitimate, even if they interfere with religious liberty. A straightforward reading of the principle would suggest that no less than other neutral measures, laws forbidding discrimination can property be applied to religious institutions. Hence the Asymmetry Thesis is not at all compelled by the Smith principle. On the contrary, the Asymmetry Thesis is in grave tension with the Smith principle, which would seem to permit application of antidiscrimination laws, facially neutral as they are. The strongest challenge to the principle is that many facially neutral laws do impose substantial burdens on religion; that they lack sufficient liberal justification; and that institutions, including judicial institutions, should not be deemed incapable of drawing the appropriate lines.

\section{Legal Possibilities}


With this background, let us now turn to the reasons why a state might be permitted to apply the ordinary civil and criminal law to religious institutions, but be proscribed from applying the law of sex discrimination to such institutions. Let us see, in short, how the Asymmetry Thesis might be defended. As we have seen, asymmetry is a common practice in many nations, whether or not it is constitutionally compelled: Even if governments are not required to exempt religious institutions from sex discrimination law, they often elect to do so.

1. Ordinary law is backed by a compelling interest, as sex discrimination law is not. The first possibility is that in principle, a state should interfere with religious practices only when it has an especially strong reason for doing so (sometimes described as a "compelling interest"). The ordinary criminal and civil law provides that reason; the law that forbids sex discrimination does not. On this view, it is one thing for a state to prohibit murder or assault. It is quite another thing for a state to forbid discriminatory practices.

There can be no doubt that an intuition of this kind helps explain current practice; indeed, I believe that it plays a large role in establishing the conventional wisdom and the Asymmetry Thesis itself. And the idea would have some force if the ordinary criminal and civil law always directed itself against extremely serious harms. But it does not. The ordinary law prohibits torts that are often relatively modest (intentional infliction of emotional distress, low-level libels, minor assaults that count as such even without physical contact). The state does not apply the tort law to religious organizations only when the underlying torts impose grave injuries. Under the Smith principle, there is no weighing of the state's interest to assess its magnitude. (Even before that case, there was little doubt that ordinary tort law could be applied to religious groups.) For example, the law against the intentional infliction of emotional distress is entirely applicable to religious institutions. Like everyone else, priests and rabbis are not permitted to tell people, falsely, that their children have just been run over by trucks, even if those people are religious enemies.

Religious organizations are thus subject to civil and criminal law prohibiting lowlevel harms. Why can't the law against sex discrimination be applied as well? At first glance, the interests behind that law are important rather than trivial. It is not easy to explain why that the interest in being free from sex discrimination is, in principle, weaker 
than the interests that underlie various aspects of the ordinary civil and criminal law. Often the interest in eliminating sex discrimination appears to be far stronger than the

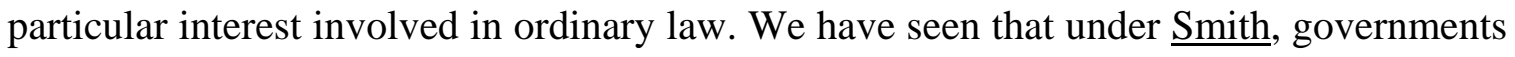
should be permitted, at least, to apply the law of sex discrimination to religious organizations. The Asymmetry Principle would seem to have no authority if $\underline{\text { Smith is }}$ right. But governments frequently exempt religious institutions from laws forbidding sex discrimination, even though they apply most of their ordinary civil and criminal law.

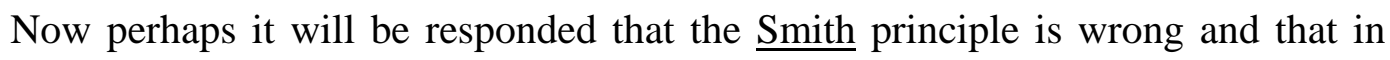
order for the state to respect liberty, the law should not apply to religious institutions unless the state has an especially strong reason for the application. This idea lay behind the 1996 Religious Freedom Restoration Act. As we have seen, that Act was invalidated by the Supreme Court in 1997 as beyond Congress' power; but it did, and does, exemplify a widely shared view about the nature of religious liberty. On that view, a degree of "balancing" is necessary; the degree of the state's intrusion into religion must be measured against the strength of the state's reason for the intrusion.

For present purposes what is important is that even if we reject the Smith principle, we need not approve of the asymmetry between the law banning sex discrimination and ordinary law. There is no reason to accept the view that ordinary law is backed by a strong or compelling interest, while the law of sex discrimination is not so backed.

2. Ordinary law does not strike at the heart of religious liberty, as sex discrimination law often would. It might be thought that a prohibition on sex discrimination would impose a substantial burden on religious beliefs and practices, or even strike at their heart, whereas the ordinary civil and criminal law does not. On this view, the Smith principle is wrong; some exemptions from ordinary law are necessary from the standpoint of religious liberty. ${ }^{11}$ But the reason for any religious exemptions is respect for religious autonomy-respect that can usually coexist with ordinary civil and criminal law, but not with the law forbidding sex discrimination. For some religious institutions, a secular mandate of a (controversial conception of) sex equality would be

\footnotetext{
11 In EEOC v. Catholic University of America, 83 F.3d 455 (DC Cir. 1994), the court held, without much explanation, that Smith did not undermine previous holdings that there was an exception for ministers from the general sex discrimination law.
} 
intolerable, whereas application for ordinary law fits comfortably, in general, with their own beliefs and practices. The Asymmetry Thesis might be squarely defended on this ground.

The argument is not entirely without force. Sometimes ordinary civil or criminal law is entirely consistent with the norms of religious institutions; indeed, such law often grows directly or indirectly out of religious norms. The prohibition against murder is a foundation of both religious and secular law; much of standard law can claim religious roots. It is for this reason that application of ordinary civil and criminal law causes no trouble for most religious organizations. The use of the law's prohibitions is compatible with, even in the service of, the goals of those organizations. And it is also possible to imagine requirements of sex equality that would go against the heart of certain religious convictions; imagine a ban on sex discrimination in the priesthood. Perhaps the Asymmetry Thesis can be defended on the view that ordinary civil and criminal law does not compromise religious practices, whereas a ban on sex equality would do exactly that.

But in its broadest form, this argument is quite fragile. Some aspects of ordinary civil and criminal law do strike against practices and beliefs that are central to some religions. Consider, for example, the law forbidding animal sacrifice or the use of drugs, or even laws forbidding certain kinds of assault and imprisonment. And some aspects of the law of sex discrimination interfere not at all with some religious beliefs and practices. For some religions, some of the time, sex equality is permissible or even mandatory; in any case it is practiced.

Now it is conceivable that as a class, ordinary civil laws coexist easily with most religious practices and beliefs, whereas the law of sex discrimination does not. But to the extent that this is so, it is a contingent, time-bound, highly empirical fact, one that bears little on the question of basic principle or the resolution of particular cases. If, for example, it were thought that the state could interfere with religious practices only when the interference was not serious, we could not justify a sharp asymmetry between ordinary law and the law of sex discrimination. We would have to proceed in a more fine-grained way; we would not endorse the Asymmetry Thesis. We would have to ask more particular questions about the relationship between the practice at issue and the legal intervention. In the end, the Asymmetry Thesis cannot be plausibly defended on the 
ground that ordinary law is a smaller intrusion into religious autonomy than is sex equality law.

3. Balancing in support of asymmetry. It would be possible to defend the Asymmetry Thesis by rejecting the Smith principle and with the suggestion that an appropriate test depends on both the strength and nature of the state's interest and on the extent of the adverse effect on religion. Under this approach, we might reach the following simple conclusions:

- A weak state interest (in preventing, let us suppose, not very harmful libels) is insufficient to justify any intrusion on religion at all;

- an illegitimate interest (in, say, weakening a religion hostile to the political status quo) is entirely off-limits;

- an “overriding” interest (in, for example, preventing murder) would justify any intrusion no matter how severe;

- a strong or "compelling” interest would justify most intrusions on religion, at least if the intrusion were not very severe.

Under this approach, most cases would therefore be easy. The hardest problems would arise where a strong or "compelling” interest were matched by a plausible claim that the interference would seriously jeopardize the continuing functioning of the relevant religion.

In principle, a standard of this sort seems a sensible one for a democratic social order to adopt. The major problem is that to accept it, we would have to have a high degree of confidence in those who would be entrusted with its administration. Such a standard would require courts (or other institutions) to decide which aspects of the civil and criminal law were sufficiently justified. Thus we could imagine reasonable judgments in favor of application, to religious institutions, of a legal ban on killing and torturing animals, but against application of a legal ban on peyote, on the ground that the former created a risk to third parties. The legitimacy of applying principles against sex discrimination to religious institutions would depend on an assessment of two factors: (1) the strength of the interest in those principles and (2) the extent of the interference with religious institutions. 
In responding to an earlier version of this essay, Susan Moller Okin raised two objections. ${ }^{12}$ First, she contended that an approach of this kind would give religious institutions an unfortunate incentive, which is to claim that sex discrimination is central to their own practices. Second, she objected that the approach would require courts to ask difficult interpretive questions about the extent to which a nondiscrimination requirement would be burdensome or harmful to religious institutions. Objections of this kind might seem to cast Smith in a more favorable light, in a way that might simply permit states to apply sex discrimination law to religious institutions. Or such objections might be used in defense of the Asymmetry Thesis, to suggest that courts ought simply to allow religious institutions to discriminate on the basis of sex whenever they contend, plausibly, that such discrimination is central to their own practices. But the question is whether the considerations that Okin marshals are decisive; and I do not believe that they are.

Whenever an apparently neutral practice is brought to bear against a religious institution, and the institution objects, there is an incentive to claim that the practice in question is central to the religion; and that incentive cannot by itself mean either that apparently neutral laws are always unacceptable or always legitimate. Okin's second claim is more powerful. To say the least, courts are unlikely to be in the best position to know whether sex discrimination is central to a religion. But under any regime that calls for a degree of balancing, courts will have to ask some questions that they are not ideally suited to answer. In some cases, the claim of centrality will clearly be unconvincing, simply because it will not fit with the usual practices of the religion. In other cases, it will have evident force. The hardest cases will have to be solved with presumptions and burdens of proof, in a way that is hardly unfamiliar to courts dealing with difficult constitutional problems.

Some of the trickiest issues will be evidentiary. When judges are asking the relevant questions, ought they to look at poll-type responses from believers? Ought they to make their own judgments about doctrinal centrality? What criteria are they looking for? Doctrinal centrality, by their own lights? Poll-type responses of believers? Expertise of scholars? At first glance, the judgments of genuine experts would be most reliable in this context as elsewhere. Assessments by members of the relevant religion would be most informative but also self-serving. We could imagine a set of possible responses.

12 See Susan Moller Okin, Is Multiculturalism Bad For Women? (1999). 
Perhaps those who seek to apply the law should have to demonstrate that it will not, in fact, operate against the core of a religion's beliefs. Perhaps those who seek to evade the law ought to be required to show that it would, in fact, do so. Presumptions would be unavoidable in the event of reasonable contestation.

I am not sure how Okin herself would have resolved this problem. She did believe that tax-exempt status should not be extended to the Catholic Church so long as it discriminates against women in hiring and institutional structure. But her own position was sensitive to the interests of oppressed religious groups, in a way that would further complicate the analysis. Apparently Okin would treat oppressed groups more favorably than those that have not been oppressed. I wonder about this distinction. In my view, the fact that a religious group has itself been subject to discrimination, or oppression, is an inadequate reason to permit it to treat women as less than equal, or to deny them fair equality of opportunity.

Doubtless different outcomes would be imaginable in different contexts, and I do not mean to sort out all of the conceivable dilemmas. My basic point is that with a balancing approach of this kind, the asymmetry between most civil and criminal law and the law banning sex discrimination could not possibly be sustained. Under the standard I am proposing, some ordinary law would not legitimately be applied to religious institutions, and some of the law banning sex discrimination could be so applied. The legal standard would force a candid assessment of the nature of the intrusion and the strength of the underlying interest-and not rest content with homilies (by no means followed with most civil and criminal law) about the legitimate autonomy of religious institutions. 


\section{Conclusions}

I offer three simple conclusions:

1. There is a plausible rationale for the principle, accepted by the United States Supreme Court, that a democratic social order should accept all laws that do not discriminate "on their face” against religious institutions and practices. This principle would require rejection of the Asymmetry Thesis, because it would authorize the application to those institutions of most civil and criminal law and also of laws forbidding sex discrimination. Though plausible, this principle is not in the end acceptable, because it would allow the state to subject religious institutions to laws that substantially burden those institutions, or even strike at their heart, without at the same time serving a sufficiently important governmental purpose.

2. It is not only plausible but also correct to say that a liberal social order should disallow facially neutral laws if they (a) interfere in a significant way with religious practices, or impose a substantial burden on religious institutions, and (b) are not supported by a legitimate and sufficiently strong justification. But this idea does not support the Asymmetry Thesis, or anything like a categorical distinction between ordinary civil and criminal law and laws forbidding sex discrimination. In many cases, the idea would allow religious institutions to immunize themselves from ordinary law, but forbid them from immunizing themselves from the law prohibiting discrimination on the basis of sex.

3. There is no plausible rationale for the view, embodied in the Asymmetry Thesis and the practices of many democratic nations, that it is unproblematic to apply ordinary civil and criminal law to religious institutions, but that it is problematic to apply, to those institutions, laws forbidding sex discrimination.

This conclusion means that there is no general barrier to applying such laws to religious institutions. Whether it is legitimate to do so depends on the extent of the interference with religious convictions and the strength of the state's justification. Reasonable people can reach different conclusions about particular cases. An especially serious problem, with implications for the resolution of hard cases, is the effects of discriminatory practices on the development of beliefs and aspirations on the part of men and women alike. It would follow that in at least some of the cases traced in part I above, 
the religious practice would have to yield. In the long-run, acceptance of this conclusion, and rejection of the Asymmetry Thesis, would be likely to have significant and salutary consequences for democratic theory and practice.

Readers with comments may address them to:

Professor Cass Sunstein

University of Chicago Law School

1111 East 60th Street

Chicago, IL 60637

csunstei@midway.uchicago.edu 


\section{The University of Chicago Law School Public Law and Legal Theory Working Paper Series}

1. $\quad$ Cass R. Sunstein and Edna Ullmann-Margalit, Second-Order Decisions (November 1999; Ethics, v.110, no. 1)

2. Joseph Isenbergh, Impeachment and Presidential Immunity from Judicial Process (November 1999; forthcoming Yale Law and Policy Review v.18 \#1).

3. Cass R. Sunstein, Is the Clean Air Act Unconstitutional? (August 1999; Michigan Law Review \#3).

4. Elizabeth Garrett, The Law and Economics of "Informed Voter" Ballot Notations (November 1999, University of Virginia Law Review, v. 85).

5. David A. Strauss, Do Constitutional Amendments Matter? (November 1999)

6. $\quad$ Cass R. Sunstein, Standing for Animals (November 1999)

7. Cass R. Sunstein, Culture and Government Money: A Guide for the Perplexed (April 2000).

8. Emily Buss, Without Peers? The Blind Spot in the Debate over How to Allocate Educational Control between Parent and State (April 2000).

9. David A. Strauss, Common Law, Common Ground, and Jefferson’s Principle (June 2000).

10. Curtis A. Bradley and Jack L. Goldsmith, Treaties, Human Rights, and Conditional Consent (May 2000; Pennsylvania Law Review v. 149).

11. Mary Ann Case, Lessons for the Future of Affirmative Action from the Past of the Religion Clauses? (May 2001, Supreme Court Review, 2000)

12. Cass R. Sunstein, Social and Economic Rights? Lessons from South Africa (May, 2000).

13. Jill Elaine Hasday, Parenthood Divided: A Legal History of the Bifurcated Law of Parental Relations (June 2001)

14. Elizabeth Garrett, Institutional Lessons from the 2000 Presidential Election (May 2001).

15. Richard A. Epstein, The Allocation of the Commons: Parking and Stopping on the Commons (August 2001).

16. Jack Goldsmith, The Internet and the Legitimacy of Remote Cross-Border Searches (October 2001).

17. Adrian Vermeule, Does Commerce Clause Review Have Perverse Effects? (October 2001).

18. Cass R. Sunstein, Of Artificial Intelligence and Legal Reasoning (November 2001).

19. Elizabeth Garrett, The Future of Campaign Finance Reform Laws in the Courts and in Congress, The William J. Brennan Lecture in Constitutional Law (December 2001).

20. Julie Roin, Taxation without Coordination (March 2002).

21. Geoffrey R. Stone, Above the Law: Research Methods, Ethics, and the Law of Privilege (March 2002; forthcoming J. Sociological Methodology 2002).

22. Cass R. Sunstein, Is There a Constitutional Right to Clone? (March 2002).

23. Emily Buss, Parental Rights (May 2002, forthcoming Virginia Law Review).

24. David A. Strauss, Must Like Cases Be Treated Alike? (May 2002).

25. David A. Strauss, The Common Law Genius of the Warren Court (May 2002).

26. Jack Goldsmith and Ryan Goodman, U.S. Civil Litigation and International Terrorism (June 2002).

27. Jack Goldsmith and Cass R. Sunstein, Military Tribunals and Legal Culture: What a Difference Sixty Years Makes (June 2002).

28. Cass R. Sunstein and Adrian Vermeule, Interpretation and Institutions (July 2002).

29. Elizabeth Garrett, Is the Party Over? The Court and the Political Process (August 2002).

30. Cass R. Sunstein, The Rights of Animals: A Very Short Primer (August 2002).

31. Joseph Isenbergh, Activists Vote Twice (November 2002).

32. Julie Roin, Truth in Government: Beyond the Tax Expenditure Budget (November 2002).

33. Cass R. Sunstein, Hazardous Heuristics (November 2002).

34. Cass R. Sunstein, Conformity and Dissent (November 2002). 
35. Jill Elaine Hasday, The Principle and Practice of Women's "Full Citizenship": A Case Study of Sex-Segregated Public Education (December 2002).

36. Cass R. Sunstein, Why Does the American Constitution Lack Social and Economic Guarantees? (January 2003).

37. Adrian Vermeule, Mead in the Trenches (January 2003).

38. Cass R. Sunstein, Beyond the Precautionary Principle (January 2003).

39. Adrian Vermeule, The Constitutional Law of Congressional Procedure (February 2003).

40. Eric A. Posner and Adrian Vermeule, Transitional Justice as Ordinary Justice (March 2003).

41. Emily Buss, Children’s Associational Rights? Why Less Is More (March 2003)

42. Emily Buss, The Speech Enhancing Effect of Internet Regulation (March 2003)

43. Cass R. Sunstein and Richard H. Thaler, Libertarian Paternalism Is Not an Oxymoron (May 2003)

44. Elizabeth Garrett, Legislating Chevron (April 2003)

45. Eric A. Posner, Transfer Regulations and Cost-Effectiveness Analysis (April 2003)

46. Mary Ann Case, Developing a Taste for Not Being Discriminated Against (May 2003)

47. Saul Levmore and Kyle Logue, Insuring against Terrorism—and Crime (June 2003)

48. Eric Posner and Adrian Vermeule, Accommodating Emergencies (September 2003)

49. Adrian Vermeule, The Judiciary Is a They, Not an It: Two Fallacies of Interpretive Theory (September 2003)

50. Cass R. Sunstein, Ideological Voting on Federal Courts of Appeals: A Preliminary Investigation (September 2003)

51. Bernard E. Harcourt, Rethinking Racial Profiling: A Critique of the Economics, Civil Liberties, and Constitutional Literature, and of Criminal Profiling More Generally (November 2003)

52. Jenia Iontcheva, Nationalizing International Criminal Law: The International Criminal Court As a Roving Mixed Court (January 2004)

53. Lior Jacob Strahilevitz, The Right to Destroy (January 2004)

54. Adrian Vermeule, Submajority Rules (in Legislatures and Elsewhere) (January 2004)

55. Jide Nzelibe, The Credibility Imperative: The Political Dynamics of Retaliation in the World Trade Organization's Dispute Resolution Mechanism (January 2004)

56. Catharine A. MacKinnon, Directions in Sexual Harassment Law: Afterword (January 2004)

57. Cass R. Sunstein, Black on Brown (February 2004)

58. Elizabeth F. Emens, Monogamy's Law: Compulsory Monogamy and Polyamorous Existence (February 2004)

59. Bernard E. Harcourt, You Are Entering a Gay- and Lesbian-Free Zone: On the Radical Dissents of Justice Scalia and Other (Post-) Queers (February 2004)

60. Adrian Vermeule, Selection Effects in Constitutional Law (March 2004)

61. Derek Jinks and David Sloss, Is the President Bound by the Geneva Conventions? (July 2004)

62. Derek Jinks and Ryan Goodman, How to Influence States: Socialization and International Human Rights Law (March 2004)

63. Eric A. Posner and Alan O. Sykes, Optimal War and Jus Ad Bellum (April 2004)

64. Derek Jinks, Protective Parity and the Law of War (April 2004)

65. Derek Jinks, The Declining Significance of POW Status (April 2004)

66. Bernard E. Harcourt, Unconstitutional Police Searches and Collective Responsibility (June 2004)

67. Bernard E. Harcourt, On Gun Registration, the NRA, Adolf Hitler, and Nazi Gun Laws: Exploding the Gun Culture Wars \{A Call to Historians\} (June 2004)

68. Jide Nzelibe, The Uniqueness of Foreign Affairs (July 2004)

69. Derek Jinks, Disaggregating “War” (July 2004) 
70. Jill Elaine Hasday, Mitigation and the Americans with Disabilities Act (August 2004)

71. Eric A. Posner and Cass R. Sunstein, Dollars and Death (August 2004)

72. Cass R. Sunstein, Group Judgments: Deliberation, Statistical Means, and Information Markets (August 2004)

73. Adrian Vermeule, Constitutional Amendments and the Constitutional Common Law (September 2004)

74. Elizabeth Emens, The Sympathetic Discriminator: Mental Illness and the ADA (September 2004)

75. Adrian Vermeule, Three Strategies of Interpretation (October 2004)

76. Cass R. Sunstein, The Right to Marry (October 2004)

77. Jill Elaine Hasday, The Canon of Family Law (October 2004)

78. Adam M. Samaha, Litigant Sensitivity in First Amendment Law (November 2004)

79. Lior Jacob Strahilevitz, A Social Networks Theory of Privacy (December 2004)

80. Cass R. Sunstein, Minimalism at War (December 2004)

81. Eric A. Posner, The Decline of the International Court of Justice (December 2004)

82. Tim Wu, The Breach Theory of Treaty Enforcement (February 2005, revised March 2005)

83. Adrian Vermeule, Libertarian Panics (February 2005)

84. Eric A. Posner and Adrian Vermeule, Should Coercive Interrogation Be Legal? (March 2005)

85. Cass R. Sunstein and Adrian Vermeule, Is Capital Punishment Morally Required? The Relevance of Life-Life Tradeoffs (March 2005)

86. Adam B. Cox, Partisan Gerrymandering and Disaggregated Redistricting (April 2005)

87. Eric A. Posner, Political Trials in Domestic and International Law (April 2005)

88. Cass R. Sunstein, Irreversible and Catastrophic (April 2005)

89. Adam B. Cox, Partisan Fairness and Redistricting Politics (April 2005, NYU L. Rev. 70, \#3)

90. Cass R. Sunstein, Administrative Law Goes to War (May 2005, Harvard L. Rev., forthcoming)

91. Cass R. Sunstein, Chevron Step Zero (May 2005)

92. Bernard E. Harcourt, Policing L.A.’s Skid Row: Crime and Real Estate Development in Downtown Los Angeles [An Experiment in Real Time] (May 2005)

93. Bernard E. Harcourt and Jens Ludwig, Broken Windows: New Evidence from New York City and a Five-City Social Experiment (May 2005)

94. Bernard E. Harcourt, Against Prediction: Sentencing, Policing, and Punishing in an Actuarial Age (May 2005)

95. Philip Hamburger, The New Censorship: Institutional Review Boards (May 2005)

96. Eugene Kontorovich, Disrespecting the "Opinions of Mankind” (June 2005)

97. Tim Wu, Intellectual Property, Innovation, and Decision Architectures (June 2005)

98. Lior Jacob Strahilevitz, Exclusionary Amenities in Residential Commons (July 2005)

99. Cass R. Sunstein, Ranking Law Schools: A Market Test? (July 2005)

100. Mary Anne Case, Pets or Meat (August 2005)

101. Adam Samaha, Executive Exposure: Government Secrets, Constitutional Law, and Platforms for Judicial Intervention (August 2005, revised November 2005)

102. Jason J. Czarnezki and William K. Ford, The Phantom Philosophy? An Empirical Investigation of Legal Interpretation (August 2005)

103. Adrian Vermeule, Absolute Voting Rules (August 2005)

104. Eric A. Posner and Adrian Vermeule, Emergencies and Democratic Failure (August 2005)

105. Adrian Vermeule, Reparations as Rough Justice (September 2005)

106. Arthur J. Jacobson and John P. McCormick, The Business of Business Is Democracy (September 2005)

107. Tracey Meares and Kelsi Brown Corkran, When 2 or 3 Come Together (October 2005)

108. Adrian Vermeule, Political Constraints on Supreme Court Reform (October 2005) 
109. Lior Jacob Strahilevitz, Information Asymmetries and the Rights to Exclude (November 2005)

110. Cass R. Sunstein, Fast, Frugal and (Sometimes) Wrong (November 2005)

111. Cass R. Sunstein, Justice Breyer’s Democratic Pragmatism (November 2005)

112. Adam M. Samaha, Endorsement Retires: From Religious Symbols to Anti-Sorting Principles (November 2005)

113. Adam M. Samaha, Undue Process: Congressional Referral and Judicial Resistance in the Schiavo Controversy (November 2005)

114. Bernard E. Harcourt, Should We Aggregate Mental Hospitalization and Prison Population Rates in Empirical Research on the Relationship between Incarceration and Crime, Unemployment, Poverty, and Other Social Indicators? On the Continuity of Spatial Exclusion and Confinement in Twentieth Century United States (January 2006)

115. Elizabeth Garrett and Adrian Vermeule, Transparency in the Budget Process (January 2006)

116. Cass R. Sunstein, Burkean Minimalism (January 2006)

117. Stephanos Bibas, Transparency and Participation in Criminal Procedure (February 2006)

118. Douglas G. Lichtman, Captive Audiences and the First Amendment (February 2006)

119. Eric A. Posner and Cass R. Sunstein, The Law of Other States (March 2006)

120. Jeff Leslie and Cass R. Sunstein, Animal Rights without Controversy (March 2006)

121. Adrian Vermeule, The Delegation Lottery (March 2006)

122. Adrian Vermeule, Self-Defeating Proposals: Ackerman on Emergency Powers (March 2006)

123. Bernard E. Harcourt, Muslim Profiles Post 9/11: Is Racial Profiling an Effective Counterterrorist Measure and Does It Violate the Right to Be Free from Discrimination? (March 2006)

124. Christine Jolls and Cass R. Sunstein, The Law of Implicit Bias (April 2006)

125. Lior Strahilevitz, “How’s My Driving?” for Everyone (and Everything?) (April 2006)

126. Jack Goldsmith and Eric A. Posner, The New International Law Scholarship (May 2006)

127. Eric A. Posner and John Yoo, International Law and the Rise of China (May 2006)

128. Eric A. Posner and Cass R. Sunstein, Chevronizing Foreign Relations Law (May 2006)

129. Jacob E. Gersen and Adrian Vermeule, Chevron as a Voting Rule (June 2006)

130. Jacob E. Gersen, Temporary Legislation (June 2006)

131. Adam B. Cox, Designing Redistricting Institutions (June 2006)

132. Adam B. Cox, The Temporal Dimension of Voting Rights (July 2006)

133. Curtis A. Bradley and Eric A. Posner, Presidential Signing Statements and Executive Power (July 2006)

134. Cass R. Sunstein, Clear Statement Principles and National Security: Hamdan and Beyond (July 2006)

135. Cass R. Sunstein, Of Snakes and Butterflies: A Reply (August 2006)

136. Cass R. Sunstein, Montreal versus Kyoto: A Tale of Two Protocols (September 2006)

137. Douglas Lichtman, Irreparable Benefits (September 2006)

138. Adam M. Samaha, Undue Process (September 2006)

139. Eric A. Posner and Adrian Vermeule, The Credible Executive (September 2006)

140. Adam B. Cox and Eric A. Posner, The Second-Order Structure of Immigration Law (November 2006)

141. Eric A. Posner, The International Protection of Cultural Property: Some Skeptical Observations (November 2006)

142. Bernard E. Harcourt and Jens Ludwig, Reefer Madness: Broken Windows Policing and Misdemeanor Marijuana Arrests in New York City, 1989-2000 (December 2006)

143. Bernard E. Harcourt, Embracing Chance: Post-Modern Meditations on Punishment (December 2006)

144. Cass R. Sunstein, Second-Order Perfectionism (December 2006) 
145. Wayne Hsiung and Cass R. Sunstein, Climate Change and Animals (January 2007)

146. Cass R. Sunstein, Deliberating Groups versus Prediction Markets (or Hayek's Challenge to Habermas) (January 2007)

147. Cass R. Sunstein, Incompletely Theorized Agreements in Constitutional Law (January 2007)

148. Eric A. Posner, Climate Change and Human Rights Litigation: A Critical Appraisal (January 2007)

149. Cass R. Sunstein, Cost-Benefit Analysis without Analyzing Costs or Benefits: Reasonable Accommodation, Balancing,a nd Stigmatic Harms (January 2007)

150. Cass R. Sunstein, Willingness to Pay versus Welfare (January 2007)

151. Cass R. Sunstein, If People Would Be Outraged by Their Rulings, Should Judges Care? (February 2007)

152. Bernard E. Harcourt, Judge Richard Posner on Civil Liberties: Pragmatic Authoritarian Libertarian (March 2007)

153. Eugene Kontorovich, What Standing Is Good For (March 2007)

154. Eugene Kontorovich, Inefficient Customs in International Law (March 2007)

155. Bernard E. Harcourt, From the Asylum to the Prison: Rethinking the Incarceration Revolution. Part II: State Level Analysis (March 2007)

156. Bernard E. Harcourt, An Answer to the Question: "What Is Poststructuralism?” (March 2007)

157. Cass R. Sunstein, Backlash’s Travels (March 2007)

158. Cass R. Sunstein, Due Process Traditionalism (March 2007)

159. Adam B. Cox and Thomas J. Miles, Judging the Voting Rights Act (March 2007)

160. Jonathan F. Mitchell, Apprendi's Domain (April 2007)

161. Jacob E. Gersen, Overlapping and Underlapping Jurisdiction in Administrative Law (April 2007)

162. Eric A. Posner and Cass R. Sunstein, On Learning from Others (April 2007)

163. Eric A. Posner and Adrian Vermeule, Originalism and Emergencies: A Reply to Lawson (April 2007)

164. Cass R. Sunstein, Illusory Losses (April 2007)

165. Josh Bowers, Punishing the Innocent (April 2007)

166. Adam M. Samaha, What Good Is the Social Model of Disability? (May 2007)

167. Cass R. Sunstein, On the Tension between Sex Equality and Religious Freedom (June 2007) 